\title{
Importance of predictive biomarkers related to Pharmacogenetics in breast cancer and prostate: a systematic review
}

\author{
Importância de biomarcadores preditivos relacionados à Farmacogenética no câncer de mama e próstata: \\ uma revisão sistemática \\ Importancia de los biomarcadores predictivos relacionados con farmacogenética en cáncer de mama y \\ próstata: una revisión sistemático
}

Received: 03/09/2021 | Reviewed: 03/16/2021 | Accept: 03/18/2021 | Published: 03/24/2021

Elisa da Silva Menezes ORCID: https://orcid.org/0000-0002-8686-0727 Universidade da Amazônia, Brasil E-mail: elisamenezes19@gmail.com

Emerson Tomas Ferreira Carneiro ORCID: https://orcid.org/0000-0002-8943-3704 Universidade da Amazônia, Brasil E-mail: emersontomas20@gmail.com

Marcella Kelly Costa de Almeida ORCID: https://orcid.org/0000-0002-3376-0976

Universidade da Amazônia, Brasil E-mail: mkca02@yahoo.com.br Carla de Castro Sant' Anna ORCID: https://orcid.org/0000-0002-7171-7071 Universidade da Amazônia, Brasil Hospital Ophir Loyola, Belém, Pará, Brasil E-mail: santannacarla@yahoo.com.br

\begin{abstract}
Pharmacogenetics allows to verify the genetic polymorphisms that influence the success of an oncological pharmacotherapy, therefore, the need for progression in the pharmacogenomic oncological field is evident. This study aims to describe the importance of predictive biomarkers related to pharmacogenetic breast and prostate cancer through a literature review. The search for original articles took place between February and November 2020 in databases such as Pubmed, Scielo, Medline and search directories such as Google Scholar. As for the inclusion criteria, the original articles in English, Portuguese and Spanish published between 2010 and 2020 were included. The search result found 102 articles on the subject, 36 excluded because they were review articles, 22 excluded after reading the abstract and 13 excluded because they did not align with the theme. 31 original articles were selected for which the authors prove the importance of validating independent studies on predictive values of biomarkers for breast and prostate cancer. The conclusion of the analyzed studies suggests that the use of biomarkers makes it possible to predict responses to clinical treatment, appropriate therapeutic conduct where they are associated with better treatment results.
\end{abstract}

Keywords: Carcinogenesis; Pharmacogenomics; Biomarker; Treatment.

\section{Resumo}

Antecedentes: Este estudo objetiva descrever a importância de biomarcadores preditivos relacionados à farmacogenética no câncer de mama e de próstata. Materiais e Métodos: A busca de artigos originais se deu entre fevereiro e novembro de 2020 em bases de dados como Pubmed, Scielo, Medline e diretórios de busca como Google Acadêmico. O critério de inclusão se deu através de artigos originais, de linguagem inglesa, portuguesa e espanhola publicados entre o ano de 2010 a 2020. Resultados: A busca encontrou 102 artigos, 36 excluídos por serem de revisão, 22 excluídos após leitura do resumo e 13 excluídos por não seguirem a temática. Foram selecionados 31 artigos originais pelos quais os autores comprovam a importância da validação de estudos independentes sobre valores preditivos de biomarcadores. Conclusão: A conclusão dos estudos analisados sugere que a utilização de biomarcadores possibilita a previsão de respostas ao tratamento clínico, conduta terapêutica adequada onde são associados a melhores resultados do tratamento.

Palavras-chave: Carcinogênese; Farmacogenômica; Biomarcador; Tratamento.

\section{Resumen}

Antecedentes: este estudio tiene como objetivo describir la importancia de los biomarcadores factores predictivos relacionados con la farmacogenética en el cáncer de mama y de próstata. Materiales y Métodos: La búsqueda de 
artículos originales se realizó entre febrero y noviembre de 2020 en un datos como Pubmed, Scielo, Medline y directorios de búsqueda como Google Scholar. La el criterio de inclusión se dio a través de artículos originales, en inglés, portugués publicado entre 2010 y 2020. Resultados: La búsqueda encontró 102 artículos, 36 excluidos para ser revisados, 22 excluidos después de leer el resumen y 13 excluidos para no sigas el tema. Se seleccionaron 31 artículos originales para los cuales los autores demostrar la importancia de validar estudios independientes sobre valores predictivos de biomarcadores. Conclusión: La conclusión de los estudios analizados sugiere que el uso de los biomarcadores permiten predecir las respuestas al tratamiento clínico, la conducta terapéutica donde se asocian con mejores resultados del tratamiento.

Palabras clave: Carcinogénesis; Farmacogenómica; Biomarcador; Tratamiento.

\section{Introduction}

According to the National Cancer Institute (INCA), in 2020, 66,280 new cases of breast cancer and 65,840 new cases of prostate cancer are estimated in Brazil. These are the neoplasms with the highest incidence in men and women in the country, therefore, it is extremely important to optimize treatment, rationalizing and individualizing antineoplastic therapy with the aid of PGx tests identifying polymorphism in specific pharmacogenes (INCA, 2021).

Pharmacogenetics (PGx) is a genetic tool that emerged in the 1950s through several observations of inheritable enzyme deficiencies that caused toxicity to certain drugs. It is the science that provides the optimization of therapeutic management in terms of safety and effectiveness, based on the genetic characteristics of patients (Álvarez et al., 2019).

Pharmacogenetic tests allow to verify the genetic polymorphisms that influence the success of a pharmacotherapy. Through the administration of personalized treatments, we can increase the number of positive responses and reduce the rate of occurrence of adverse reactions and toxicity (Fricke et al., 2018). The preference for the application of PGx tests in the area of oncology is due to its aggressiveness, rapid proliferation of cancer cells and the severity of symptoms. In the clinical context, PGx has shown great importance in the treatment of prostate and breast cancer. Which are the most prevalent cancers among men and women in Brazil (Schilling et al., 2017).

Thus, it is essential to set goals that allow this therapeutic approach to be included as an important portion of pharmacotherapy, being present in hospital and outpatient settings. Increasingly relevant, scientific information is able to allow the personalization of therapy, where PGx, pharmacodynamics and pharmacokinetics, needs to be assimilated and used by pharmacists in order to promote an increase in the patient's quality of life, through greater efficiency and drug safety (Santos, 2017).

Therefore, the use of PGx tests allows cancer patients to experience an individualized treatment, with the correct, specific, safe drug, with the most appropriate and consequently more effective dosage and with a lower incidence of adverse effects during chemotherapy. It is also considered, the significant advance in the area of molecular oncology, or oncobiology, taking into account the adoption of PGx and pharmacogenomics, resulting in positive consequences in the enhancement and improvement of pharmacological treatment. The accessibility to these genetic tests is increasing, since the values are increasingly lower, making it possible to use them in clinical practice as a medullary tool in the fight against cancer (Santos et al., 2016).

Thus, the objective of the study was to describe the importance of pharmacogenetic tests in the treatment of breast and prostate cancer in clinical practice, through a systematic review, analyzing the main predictive biomarkers for these neoplasms.

\section{Methodology}

It was a study with an investigative approach constituted by a qualitative systematic review, carried out according to the checklist of the PRISMA protocol, with data collection from bibliographic searches in the period between February to November 2020. 
The study took place through articles, mainly national and foreign, in addition to original articles, related to breast and prostate cancer and PGx. The sources were selected from the year of publication 2010 and addressing the topic of pharmacogenomics, precision medicine, breast and prostate cancer, predictive biomarkers and the importance of applying PGx tests in the therapy of cancer patients.

Articles in English, Portuguese and Spanish were selected from digital platforms: Medical Literature Analysis and Retrieval System Online (MEDLINE), PubMed, Scientific Electronic Library (SCIELO) and the Google Scholar directory, in addition to sites like INCA. Research carried out in the period between February and November 2020, searched through descriptors in English, Portuguese and Spanish such as: pharmacogenetics, breast cancer, pharmacogenomics, prostate cancer, personalized medicine, precision medicine, predictive biomarkers and molecular markers.

For the elaboration of this study, articles and research on technological development in health related to the pharmacogenetics of breast and prostate cancer were included, with publication date from 2010, in addition to original articles, field research and clinical studies.

Exclusion criteria were non-original articles, review articles, articles that address pharmacogenetics in other types of cancer, which are irrelevant, not aligned with the issue at hand and with a publication date prior to the year 2010.

The articles selected within the inclusion criteria were presented in order to describe the results. The main results were summarized in tables, generated in Microsoft Office Excel, for better visualization of the data.

\section{Results}

\section{Prostate Cancer}

The search strategy identified 61 articles. Of this total, 28 were excluded because they were duplicated and / or the study model was based on a literature review, leaving 33 original articles. When reading the abstracts, 6 articles were excluded because they did not address the topic in question, leaving 27 articles read in full. After reading and analyzing the articles in full, 12 were excluded because they did not fit the research theme and finally, 15 were selected (Figure 1).

The main information about the 15 studies used in our results can be found in Table 1.

Table 1. Main information about studies associated with predictive biomarkers in the pharmacogenetics of prostate cancer.

\begin{tabular}{|c|c|c|c|c|}
\hline Author / Year & Study title & Objective of the study & Biomarker & Study outcome \\
\hline $\begin{array}{l}\text { Armstrong et al, } \\
2017\end{array}$ & $\begin{array}{l}\text { MicroRNA-181a } \\
\text { promotesdocetaxelresistance in prostate } \\
\text { cancercells }\end{array}$ & $\begin{array}{c}\text { Understanding the } \\
\text { involvement of miRNAs } \\
\text { in docetaxel resistance in } \\
\text { CRPC }\end{array}$ & miR-181a & $\begin{array}{c}\text { Significant expression } \\
\text { of miR-181a in } \\
\text { docetaxel-resistant } \\
\mathrm{CaP} \text { cells and by } \\
\text { inhibiting them, they } \\
\text { are resensitized }\end{array}$ \\
\hline $\begin{array}{l}\text { Markowsk et al, } \\
2017\end{array}$ & $\begin{array}{l}\text { Clinical Utility of CLIA-Grade AR-V7 } \\
\text { Testing in Patients With Metastatic } \\
\text { Castration-Resistant Prostate Cancer }\end{array}$ & $\begin{array}{l}\text { To investigate the } \\
\text { clinical utility of the AR- } \\
\text { V7 test in patients with } \\
\text { (mCRPC). }\end{array}$ & AR-V7 & $\begin{array}{l}\text { The detection of AR- } \\
07+\text { and / or AR-V7- } \\
\text { can guide the clinical } \\
\text { treatment of mCRPC. }\end{array}$ \\
\hline $\begin{array}{l}\text { Antonarakis, et } \\
\underline{\text { al }}, 2017\end{array}$ & $\begin{array}{c}\text { Clinical Significance of Androgen } \\
\text { Receptor Splice Variant-7 mRNA } \\
\text { Detection in Circulating Tumor Cells of } \\
\text { Men With Metastatic Castration- } \\
\text { Resistant Rostate Cancer Treated With } \\
\text { First- and Second-Line Abiraterone and } \\
\text { Enzalutamide }\end{array}$ & $\begin{array}{l}\text { Expand studies on the } \\
\text { effectiveness of AR-V7 } \\
\text { as a marker for mCRPC } \\
\text { treatment selection }\end{array}$ & AR-V7 & $\begin{array}{l}\text { Negative results in the } \\
\text { detection of AR-V7, } \\
\text { based on CTC, were } \\
\text { confirmed in patients } \\
\text { with mCRPC, } \\
\text { impacting the } \\
\text { treatment decision. }\end{array}$ \\
\hline
\end{tabular}


Neuroendocrine differentiation markers guide treatment sequence selection in

Fan et al, 2019 metastatic castration-resistant prostate cancer
Assess the value of serum neuroendocrine markers in choosing the strategic sequence of mCRPC treatment
The results concluded that in mCRPC high levels of NED indicate better clinical results directed in DP-AA than with AA-DP
Bone Turnover Markers as Predictors of Mortality Risk in Prostate Cancer

Jung et al, 2011 . Patients with Bone Metastases Following Treatment with Zoledronic Acid
To evaluate the predictive capacity of serum bone markers for mortality risk in patients with PC with bone metastases
The ability of markers as predictors of OS

PINP e ICTP was proven, implying clinical advantages in the management of treatment
Investigate the possible association between the

AR-V7 and Resistance to Enzalutamide Antonarakis et al, 2014 detection of AR-V7 with resistance to

AR-V7

enzalutamide and abiraterone
The association between the variant AR-V7 and resistance to enzalutamide and abiraterone is concluded. quantification of

An RNA-based digital circulating tumor cell signature is predictive of drug response and early

Miyamoto et al, 2018
Digital signature of prostate CTC in noninvasive monitoring to guide treatment selection
AR-V7 transcripts derived from CTCs is predictive of treatment in mCRPC and early spread in localized $\mathrm{CaP}$

The segregation of the three $\mathrm{CaP}$ subtypes demonstrated that

Associations of Luminal and Basal Subtyping

of Prostate Cancer With Prognosis and

Zhao et al, 2017

Response to Androgen Deprivation herapy
Investigate prostate cancer subtypes based on

luminal and basal

lineage and associate them with clinical results and treatment

\section{NKX3.1, KRT18} and $\mathrm{CD} 49 \mathrm{f}$ patients with luminal B tumors respond better to postoperative ADT enabling the customization of ADT treatment

The results showed that ProsVue

Assessing a patient's ProsVue results affects medical decision-making related to secondary Cap treatment
NADiA PSA significantly reduced the number of recommendations for post-PR treatments

It was confirmed that the GC test makes it possible to change the of the Predipher genomic prediction model in the decision making of urologists for patients at risk of metastasis

GC treatment

recommendation after

PR, among other

benefits to patients and the health system

With the results, there

Evaluate the Prolaris test in providing risk of $\mathrm{CaP}$ progression and mortality while further assessing the impact on was an increase and

reduction in the

interventional treatment according to 


\begin{tabular}{|c|c|c|c|c|}
\hline & & $\begin{array}{l}\text { medical treatment } \\
\text { recommendations }\end{array}$ & & $\begin{array}{l}\text { the specific risk } \\
\text { shown in the test }\end{array}$ \\
\hline $\begin{array}{l}\text { Badani et al, } \\
2014\end{array}$ & $\begin{array}{l}\text { Effect of a genomic classifier test on } \\
\text { clinical practice decisions for patients } \\
\text { with high-risk prostate cancer after } \\
\text { surgery }\end{array}$ & $\begin{array}{l}\text { Predict the risk of } \\
\text { metastasis after PR and } \\
\text { assist in urologist } \\
\text { decision making in } \\
\text { adjuvant treatment based } \\
\text { on the genomic } \\
\text { classification test }\end{array}$ & GC & $\begin{array}{l}\text { The test found an } \\
\text { increase in the } \\
\text { clinician's ability to } \\
\text { discriminate against } \\
\text { those who are less } \\
\text { likely to experience } \\
\text { disease progression, } \\
\text { resulting in the best } \\
\text { treatment strategy }\end{array}$ \\
\hline $\begin{array}{l}\text { Shore et al, } \\
2016\end{array}$ & $\begin{array}{c}\text { Impact of the CCP test on physician and } \\
\text { patient treatment selection for localized } \\
\text { prostate cancer }\end{array}$ & $\begin{array}{l}\text { Molecular assay for } \\
\text { progression and risk of } \\
\text { mortality when } \\
\text { combined with clinical- } \\
\text { pathological parameters. }\end{array}$ & СCP & $\begin{array}{l}\text { The result of the CCP } \\
\text { test brought a } \\
\text { significant change in } \\
\text { the clinical treatment } \\
\text { strategy }\end{array}$ \\
\hline $\begin{array}{l}\text { [Someya et al, } \\
2018\end{array}$ & $\begin{array}{c}\text { Prediction of acute gastrointestinal } \\
\text { andgenitourinary radiation toxicity in } \\
\text { prostatecancerpatients using lymphocyte } \\
\text { microRNA }\end{array}$ & $\begin{array}{l}\text { Investigate new } \\
\text { biomarkers that can } \\
\text { predict acute radiation } \\
\text { toxicity through } \\
\text { microRNA expression }\end{array}$ & $\begin{array}{l}\mathrm{miR}-410 \text { and } \mathrm{miR}- \\
221\end{array}$ & $\begin{array}{c}\text { The results proved to } \\
\text { be assertive to predict } \\
\text { acute gastrointestinal } \\
\text { toxicity from radiation } \\
\text { therapy }\end{array}$ \\
\hline $\begin{array}{l}\text { Michalopoulos } \\
\text { et al, } 2014\end{array}$ & $\begin{array}{l}\text { Influence of a genomic classifier on } \\
\text { post-operative } \\
\text { treatment decisions in high-risk prostate } \\
\text { cancer } \\
\text { patients: results from the PRO-ACT } \\
\text { study }\end{array}$ & $\begin{array}{l}\text { To evaluate the possible } \\
\text { metastasis prediction } \\
\text { after PR from the PRO- } \\
\text { ACT multicentre study }\end{array}$ & GC & $\begin{array}{c}\text { Test results } \\
\text { significantly changed } \\
\text { urologists' adjuvant } \\
\text { treatment } \\
\text { recommendations for } \\
\text { post-PR patients with } \\
\mathrm{CaP} \text { and risk of } \\
\text { metastasis }\end{array}$ \\
\hline
\end{tabular}

Legend: miR-181a: microRNA-181a; AR-V7: variant 7 of the androgen receptor splice; NED: serum neuroendocrine differentiation; PINP: the amino terminals of procollagen type I collagen peptides; ICTP: cross-linked type I collagen C-terminal telopeptides; KRT18: keratin 18; NKX3.1: Related NK3 transcription factor, locus 1 (Drosophila); CD49f: Integrin $\alpha 6$; NADiA: nucleic acid detection immunoassay; PSA: prostate specific antigen; CG: genomic classifier; CCP: cell cycle progression test; miR-410: microRNA 410; miR-221: microRNA221. Source: Authors.

\section{Breast Cancer}

The search strategy identified 41 articles. Of this total, 8 were excluded because they were duplicated and / or the study model was based on a literature review, leaving 33 original articles. When reading the abstracts, 16 articles were excluded because they did not address the topic in question, leaving 17 articles read in full. After reading and analyzing the articles in full, 1 was excluded for not adapting the research topic. Thus, 16 articles were selected (Figure 1).

The main information about the 16 studies used in our results can be found in Table 2 . 
Table 2. Main information about the studies associated with predictive Biomarkers in the pharmacogenetics of breast cancer.

\begin{tabular}{|c|c|c|c|c|}
\hline $\begin{array}{l}\text { Author / } \\
\text { Year }\end{array}$ & Study title & Objective of the study & Biomarkers & Study outcome \\
\hline $\begin{array}{c}\text { Kurozumi et } \\
\text { al, } 2015 .\end{array}$ & $\begin{array}{l}\text { ER, PgR, Ki67, p27 (Kip1) and } \\
\text { histological grade as predictors of } \\
\text { complete pathological response in } \\
\text { patients with HER2-positive breast } \\
\text { cancer receiving neoadjuvant } \\
\text { chemotherapy using taxanes } \\
\text { followed by fluorouracil, epirubicin } \\
\text { and concomitant cyclophosphamide } \\
\text { with trastuzumab }\end{array}$ & $\begin{array}{l}\text { Determine whether pCR was } \\
\text { related to histological grade } \\
\text { (HG) and to several biological } \\
\text { factors, including p27 (Kip1). E } \\
\text { Also assess the prognosis of the } \\
\text { pCR and non-pCR groups, and } \\
\text { the expected differences } \\
\text { between those positive and } \\
\text { negative for lymph node } \\
\text { metastases after chemotherapy. }\end{array}$ & $\begin{array}{l}\text { HG, ER, PgR, } \\
\text { Ki67 and p27 } \\
\text { (Kip1). }\end{array}$ & $\begin{array}{l}\text { High HG, low ER, low } \\
\text { PgR, high Ki67 and low } \\
\text { p27 (Kip1) were identified } \\
\text { as predictive factors for } \\
\text { pCR in NAC with } \\
\text { trastuzumab, while pCR and } \\
\text { negative nodules were } \\
\text { predictive of better survival. }\end{array}$ \\
\hline $\begin{array}{c}\text { Carrasco et al, } \\
2011 .\end{array}$ & $\begin{array}{c}\text { Antisense Inhibition of Survivin } \\
\text { Expression as } \\
\text { a CancerTherapeutic }\end{array}$ & $\begin{array}{l}\text { Identification of survivin } \\
\text { oligonucleotide (ASO) that } \\
\text { downregulates survivin } \\
\text { expression and also shows that } \\
\text { inhibition of survivin } \\
\text { expression by LY2181308 } \\
\text { sensitized tumor cells to } \\
\text { chemotherapy-induced } \\
\text { apoptosis. }\end{array}$ & Survivina & $\begin{array}{l}\text { Inhibition of survivin } \\
\text { expression by LY2181308 } \\
\text { sensitized tumor cells to } \\
\text { chemotherapy-induced } \\
\text { apoptosis. }\end{array}$ \\
\hline
\end{tabular}

\begin{tabular}{|c|c|c|c|c|}
\hline $\begin{array}{c}\text { Hao et al, } \\
2020\end{array}$ & $\begin{array}{l}\text { Analysis of Circulating Tumor } \\
\text { DNA to Predict Neoadjuvant } \\
\text { Therapy Effectiveness and Breast } \\
\text { Cancer Recurrence }\end{array}$ & $\begin{array}{l}\text { Assess the benefits for the } \\
\text { management of breast cancer in } \\
\text { neoadjuvant therapy }\end{array}$ & $\begin{array}{l}\text { Circulating } \\
\text { tumor DNA } \\
\text { (ctDNA) }\end{array}$ & $\begin{array}{l}\text { Highlight the potential of } \\
\text { ctDNA analysis at different } \\
\text { points in time to assess } \\
\text { tumor progression and } \\
\text { treatment effectiveness, } \\
\text { such as predicting breast } \\
\text { cancer recurrence }\end{array}$ \\
\hline $\begin{array}{c}\text { Zhou et al, } \\
2020 .\end{array}$ & $\begin{array}{l}\text { CXCR4 Antagonist AMD3100 } \\
\text { Reverses } \\
\text { the Resistance to Tamoxifen in } \\
\text { Breast Cancer } \\
\text { via Inhibiting AKT } \\
\text { Phosphorylation. }\end{array}$ & $\begin{array}{c}\text { Explore the importance of the } \\
\text { CXC type } 4 \text { chemokine receptor } \\
\text { (CXCR4) in tamoxifen-treated } \\
\text { breast cancer and tamoxifen } \\
\text { resistance }\end{array}$ & CXCR4 & $\begin{array}{l}\text { The AMD3100 CXCR4 } \\
\text { antagonist reversed } \\
\text { tamoxifen resistance in } \\
\text { breast cancer. The } \\
\text { relationship between } \\
\text { tamoxifen and AMD3100 } \\
\text { increases the tumor } \\
\text { suppressor effects and } \\
\text { reduces the side effects } \\
\text { caused by the dosage of the } \\
\text { drug. }\end{array}$ \\
\hline $\begin{array}{c}\text { Zhou et al, } \\
2020\end{array}$ & $\begin{array}{l}\text { High expression of TRAF4 predicts } \\
\text { poor prognosis in } \\
\text { tamoxifen-treated breast cancer and } \\
\text { promotes tamoxifen } \\
\text { resistance }\end{array}$ & $\begin{array}{c}\text { Seek to explore the roles of } \\
\text { TRAF4 in tamoxifen -treated } \\
\text { breast cancer and tamoxifen } \\
\text { resistance }\end{array}$ & TRAF4 & $\begin{array}{l}\text { TRAF4 is strongly related } \\
\text { to a poor prognosis of } \\
\text { breast cancer treated with } \\
\text { tamoxifen. Involved in } \\
\text { tamoxifen resistance }\end{array}$ \\
\hline $\begin{array}{c}\text { Vázquez et al, } \\
2019\end{array}$ & $\begin{array}{l}\text { MicroRNA-143 is Associated With } \\
\text { Pathological Complete Response } \\
\text { and Regulates Multiple Signaling } \\
\text { Proteins in Breast Cancer }\end{array}$ & $\begin{array}{l}\text { Show that miR- } 143 \text { can be a } \\
\text { predictor of complete } \\
\text { pathological response to } \\
\text { neoadjuvant chemotherapy in } \\
\text { breast cancer patients }\end{array}$ & MicroRNA-143 & $\begin{array}{l}\text { MiR-143 could be a } \\
\text { potential predictor of } \\
\text { response to neoadjuvant } \\
\text { therapy, and also provide } \\
\text { clues to the molecular } \\
\text { functions of miR-143 in } \\
\text { signaling networks related } \\
\text { to carcinogenesis in breast } \\
\text { cancer. }\end{array}$ \\
\hline
\end{tabular}


Predictive factors of pathologic complete response in HER2-

Ding et al, positive and axillary lymph node 2017 positive breast cancer after neoadjuvant paclitaxel, carboplatin plus with trastuzumab
Investigate the proportion, as well as predictive factors of complete pathological response in HER2-positive breast cancer
Ki67

The preoperative $\mathrm{PCH}$ regimen was an effective neoadjuvant therapy in HER2 positive patients and positive axillary lymph nodes, and patients who coexisted with negative HR and a high Ki67 index could benefit more from this regimen.

Ki67 expression in HR negative breast cancer may improve the assessment of pathological response after

To evaluate the benefit of the Ki67 assessment in HRnegative breast cancers after neoadjuvant chemotherapy (NAC)
Ki67 NAC, and the Ki67 score in residual tumor was an independent predictor for DFS in HR negative breast cancer patients

Trastuzumab offered an improvement in HER-2

Check data on the clinical use and efficacy of trastuzumab in the treatment of early and advanced breast cancer
Trastuzumab positive breast cancer therapy. It has wide acceptability and greatness in the treatment of breast cancer

\begin{tabular}{|c|c|c|c|c|}
\hline $\begin{array}{c}\text { Manica et al, } \\
2017\end{array}$ & $\begin{array}{c}\text { Down regulation of ADAM33 as a } \\
\text { Predictive Biomarker of Aggressive } \\
\text { Breast Cancer }\end{array}$ & $\begin{array}{c}\text { Produce monoclonal antibodies } \\
\text { against the ADAM33 protein } \\
\text { and investigate the role of the } \\
\text { ADAM33 protein in breast } \\
\text { cancer }\end{array}$ & ADAM33 & $\begin{array}{l}\text { Showing ADAM33, in } \\
\text { combination with currently } \\
\text { available biomarkers, may } \\
\text { be a new molecular marker } \\
\text { for better determining } \\
\text { breast cancer prognosis. }\end{array}$ \\
\hline $\begin{array}{l}\text { Kim et al, } \\
2014\end{array}$ & $\begin{array}{c}\text { Yes-associated protein (YAP) is } \\
\text { differentially expressed in tumor } \\
\text { and stroma according to the } \\
\text { molecular } \\
\text { Subtypeofbreastcancer }\end{array}$ & $\begin{array}{l}\text { To clarify the expression } \\
\text { profiles of Yes-associated } \\
\text { protein (YAP) and } \\
\text { phosphorylated YAP protein } \\
\text { (pYAP) and to verify the } \\
\text { clinical implication of YAP } \\
\text { protein expression in human } \\
\text { breast cancer }\end{array}$ & YAP e pYAP & $\begin{array}{l}\text { There was a significant } \\
\text { difference in the expression } \\
\text { status of YAP and Pyap. } \\
\text { We found that the nuclear } \\
\text { and cytoplasmic expression } \\
\text { of YAP may be a } \\
\text { prognostic marker for breast } \\
\text { cancer patients }\end{array}$ \\
\hline $\begin{array}{l}\text { Shokouh et al, } \\
2015\end{array}$ & $\begin{array}{l}\text { Interrelationships Between Ki67, } \\
\text { HER2/neu, p53, ER, and PR } \\
\text { Status and Their Associations With } \\
\text { Tumor Grade and Lymph } \\
\text { Node Involvement in Breast } \\
\text { Carcinoma Subtypes }\end{array}$ & $\begin{array}{l}\text { To verify the interrelationships } \\
\text { of these predictive and } \\
\text { prognostic factors, as well as } \\
\text { their effects on breast } \\
\text { carcinoma subtypes }\end{array}$ & $\begin{array}{l}\text { Ki67, HER2 / } \\
\text { neu, p53, ER e } \\
\text { status de PR }\end{array}$ & $\begin{array}{l}\text { Tumors with a higher Ki67 } \\
\text { index showed more HER2 / } \\
\text { neu overexpression, larger } \\
\text { size and more lymph node } \\
\text { involvement compared to } \\
\text { other types and can be } \\
\text { considered aggressive. } \\
\text { Young patients with breast } \\
\text { carcinoma, Ki67 rates with } \\
\text { overexpression of HER2 / } \\
\text { neu and p53 mutations are } \\
\text { higher and have a more } \\
\text { aggressive behavior. }\end{array}$ \\
\hline Bownes, 2019 & $\begin{array}{l}\text { On-treatment biomarkers can } \\
\text { improve prediction of response to } \\
\text { neoadjuvant chemotherapy in breast }\end{array}$ & $\begin{array}{l}\text { Study changes in gene } \\
\text { expression that affect the } \\
\text { treatment of breast cancer }\end{array}$ & AAGAB & $\begin{array}{l}\text { The study resulted in the } \\
\text { discovery of a new } \\
\text { biomarker, showed }\end{array}$ \\
\hline
\end{tabular}


Research, Society and Development, v. 10, n. 3, e51810313713, 2021

(CC BY 4.0) | ISSN 2525-3409 | DOI: http://dx.doi.org/10.33448/rsd-v10i3.13713

cancer

potential in the precision of

breast cancer treatment

Asiaf et al,

2018

MicroRNAs in Breast Cancer:

Diagnostic and Therapeutic Potential
Discuss the role of miRNAs as oncogenes and tumor suppressors in the development and metastasis of breast cancer
MiRNAs have a prognostic, diagnostic or predictive potential in breast cancer, as well as possible challenges in translating such observations into the clinic

\begin{tabular}{cc}
\hline Klopp- & $\begin{array}{c}\text { Integrated Data Analysis of Six } \\
\text { Clinical Studies Points Toward } \\
\text { Schulze et al, } \\
2020\end{array}$ \\
Model-Informed Precision Dosing \\
of Tamoxifen
\end{tabular}

Dissect various levels of

variability and identify predictive factors for exposure to endoxifene and (ii) evaluate different dosages of tamoxifen strategies for its potential to increase the number of patients reaching target concentrations of endoxifene
MicroRNA

CYP3A e

CYP2D6

MIPD has proved to be the most promising strategy for reaching target concentrations of endoxifene

\section{Evaluation of the TRPM2}

channel as a biomarker in

Sumoza-

Toledo et al, 2016 breast cancer using public databases analysis
Investigate the prognostic value of the TRPM2 channel in breast cancer
TRPM2 is a promising biomarker for the

TRPM2 aggressiveness of breast cancer and a potential target for the development of new therapies

Legend: HG: histological grade; ER: estrogen receptor; PgR: progesterone receptor; Ki67: proliferating protein; p27: The cyclin 1Bdependent kinase inhibitor; CXCR4: type 4 chemokine receptor; TRAF4: factor 4 associated with the TNF receptor; ADAM33: Protein Containing Disintegrin Domain and Metalloproteinase; YAP and pYAP: protein associated with Yes and the phosphorylated YAP protein; HER2 / neu: human epidermal growth factor 2 receptor; p53: tumor protein; AAGAB: alpha-binding protein and gamma-adaptin; CYP3A and CYP2D6: cytochrome P450 and CYP2D6 enzyme; TRPM2: cationic channel of the potential transient receptor, subfamily M, member 2. Source: Authors.

Figure 1 - Flowchart of bibliographic research and selection of articles.

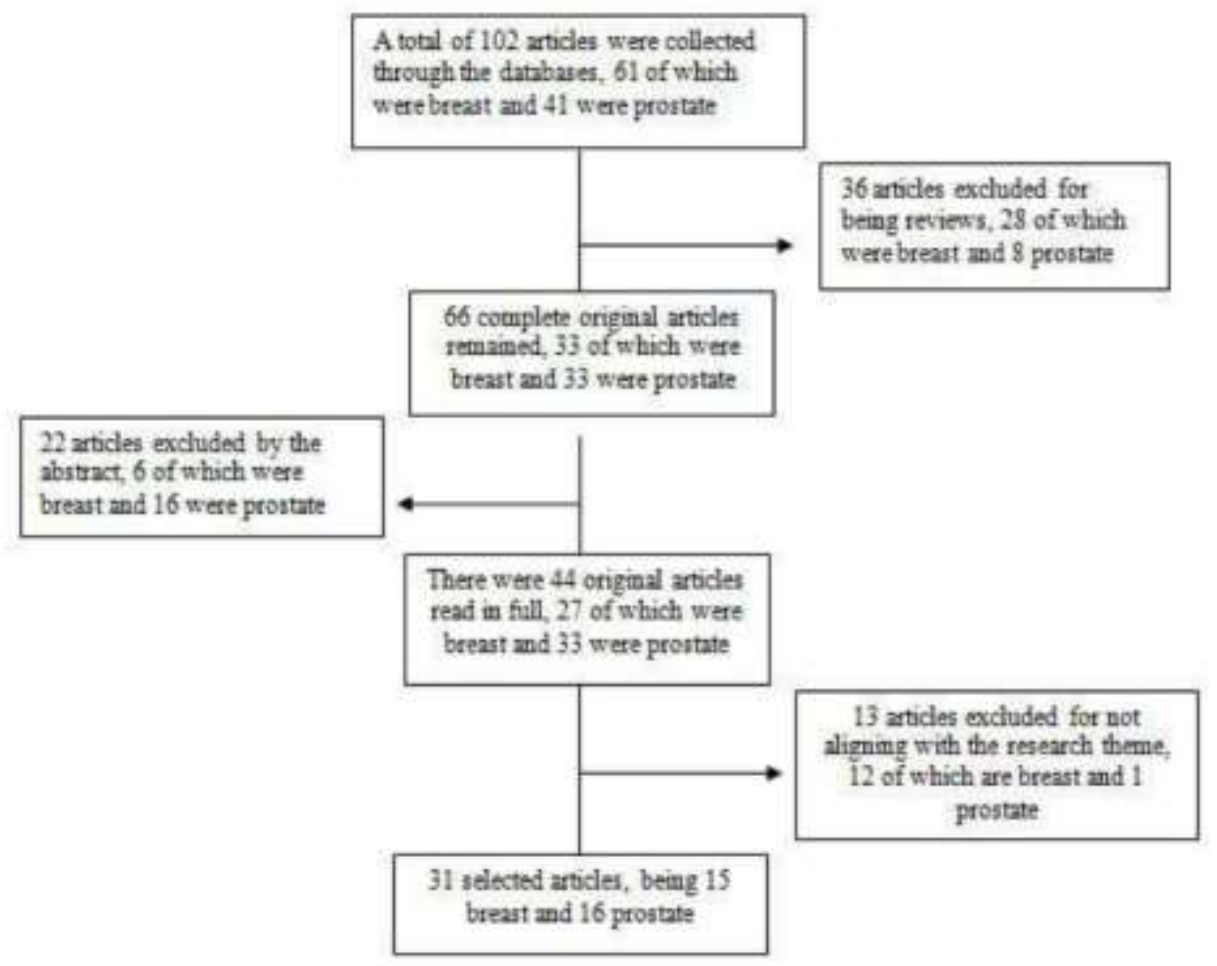

Source: Authors. 


\section{Discussion}

\section{Prostate cancer}

The tumor marker most used in the diagnosis and prognosis of prostate cancer is the prostate specific antigen (PSA), however, its contribution is limited because this marker is specific for the prostate and not only for malignancy, therefore, in cases of pathologies such as benign prostatic hyperplasia and prostatitis serum PSA levels may also be elevated (Almeida et al., 2007; Saxby et al., 2020). Therefore, validating new biomarkers that optimize the evaluation of the response to CaP treatment would benefit patients with individualized therapies. In this review we seek to explore relevant studies that focus on promising biomarkers in the clinical management of men diagnosed with PCa.

Patients with castration-resistant prostate cancer (CRPC) are directed to two main antiandrogen drugs (enzalutamide and abiraterone). This medication class meant an advance in the treatment of this neoplasia, in relation to the treatment with androgen deprivation therapy (TPA), improving the quality of life and the overall survival of these men. However, 20-40\% of patients treated with these drugs do not benefit from their effects because they acquire primary resistance and almost all have secondary resistance. One study shows the association between resistance to enzalutamide and abiraterone, the detection in CTCs of messenger RNA variant 7 of the androgen receptor splice (AR-V7) and PSA results (Antonarakis et al., 2014). The authors show that 31 patients received treatment with enzalutamide and 31 with abiraterone and PSA measurements were obtained every 1 and 2 months. Thus, 39\% and 19\% of patients respectively had AR-V7 expressed as CTCs in blood samples, in addition, AR-V7 negative patients had lower PSA response rates and longer PSA progression-free survival and overall survival, the which means that this androgen receptor isoform encoded by the splice variant 7 may represent a predictive biomarker for treatment with antiandrogen drugs, since the expression of AR-V7 in these patients with CRPC does not indicate any form of resistance to taxane chemotherapy. In addition, a study conducted in Canada and the United States has shown that the use of the AR-V7 test can impact decision-making when choosing therapy. Patients with positive AR-V7 were those who had the greatest changes in therapeutic management, which led to clinical improvement due to the use of taxanes (Markowshi et al., 2017).

Another molecular group that is linked to drug resistance in the treatment of CaP are miRNAs. Small RNAs of approximately 22 nucleotides, which at the post-transcriptional level negatively regulate gene expression and when deregulated can serve as oncogenes or tumor suppressing agents. These RNAs can be detected in the serum and serve as predictive biomarkers in resistance to chemotherapy drugs such as docetaxel (Shi et al., 2010). In a study whose objective was to characterize the role of miR-181a in docetaxel-resistant prostate cancer, it measured the expression of miR-181a in C4-2B and DU145 parental and docetaxel-resistant cells in TaxR (DU). It was concluded that the expression of miR-181a is elevated in TaxR cells (8.6 times) and DU145-DTXR (7.4 times) compared to parental C4-2B and DU145 cells, respectively. Overexpression of miRNA-181a significantly improved cell survival in the presence of docetaxel (ie, resisted this treatment) compared to the miR mimicking control in parental C4-2B cells. However, docetaxel-resistant TaxR cells were resensitized by miR-181 to that same drug. The same study also demonstrated cross-resistance to cabazitaxel and resensitization of miR-181a TaxRcomknockdown cells. Thus, these findings are significantly relevant and may contribute to a more appropriate choice of therapy for the patient that presents data that prove resistance to docetaxel (Armstrong et al., 2017).

Another promising proposal for the treatment of patients with $\mathrm{CaP}$ is the neuroendocrine biomarkers. Neuroendocrine differentiation (NED) is equivalent to the association of unfavorable prognosis and serum levels of chromogranin $\mathrm{A}(\mathrm{CgA})$ and neuron specific enolase (NSE), neuropeptides stored in neuroendocrine cells (Genitsch et al., 2017). Study aimed to assess the value of the markers (NED) to help select the best treatment sequence for abiraterone acetate (AA) and docetaxel-prednisone (DP) in men with mCRPC, showed through blood samples from 88 patients, the levels ofCgA and NSE measured before first line treatment. Patients with a high level of baseline NED markers proved to be more beneficial in receiving a sequence of DP- 
AA treatment instead of AA-DP. This group of men had an overall median survival of 21.7 months with DP-AA treatment and 19.9 months with AA-DP treatment, respectively. In addition, the same study found that a patient with mCRPC with elevated serum NED levels, has a response to chemotherapy with PD, decreased levels of NED. According to the authors, this fact is related to patients with high baseline NED levels that respond better to the DP-AA sequence instead of the AA-DP (Fan et al., 2019).

Almost $100 \%$ of patients with mCRPC have bone metastasis. These terminally ill men suffer from severe progressive pain, among other consequences of this distension. Bone metabolism occurs through the synthesis of new bone mediated by osteoblasts and bone resorption mediated by osteoclasts. This process is regulated by the balance between the two phenomena, however, in patients with mCRPC this homeostasis is not regulated and ends up being compromised by emphasizing the activity of osteoblasts and, therefore, favoring bone formation (Lara et al., 2014). A prospective multicenter study with the objective of evaluating the predictive capacity of serum bone markers in patients with mCRPC and the risk of mortality was developed between 2002 and 2005 with 52 patients. In the result, it was observed that 34 patients died and 18 were alive at the time of the last evaluation, where the concentrations of bone markers, mainly ICTP and PINP, were higher in the group of deceased compared to survivors $(\mathrm{p}<0.05)$ and that the combination of these markers is able to predict mortality in the next 24 months in the analysis performed where AUC values $>0.7$ were presented, with sensitivities / specificities between $70 \%$ and $80 \%$. Therefore, patients with advanced mCRPC can especially benefit from ICTP and PINP markers as predictors of survival both to be aware of their health status and for the physician to rethink the best additional therapeutic management (Jung et al., 2011).

\section{Breast cancer}

Breast cancer is a prevalent malignancy in the female population, as it is a complex disease, several factors interfere with the prognosis and the outcome of a specific therapeutic regimen. Each type of breast cancer has a different behavior, precisely because these neoplastic cells express hormone receptors (estrogen and / or progesterone) and HER2 protein, causing the cancer to vary its way of tumor progression (Manica et al., 2017). The present study was therefore conducted by analyzing the status of different predictive factors in breast carcinoma subtypes, elucidating the correlations of these factors, in order to identify significant relationships between the types of breast cancer. It is necessary to identify predictive biomarkers that assist in individualized therapy in view of the heterogeneities of breast neoplasms.

Studies have observed the relationship of dasurvivin, a member of the apoptosis protein inhibitor family, as an attractive target for treatment against various carcinogens. Survivin expression is constantly related to poor prognosis in a wide variety of cancer patients. To express the expression of survivin, ASOs (survivin oligonucleotide) were employed, which negatively regulates the expression of survivin in human cancer cells, in an attempt to create another therapeutic drug, showing that the function or inhibition of survivin by the oligonucleotide LY2181308 boosted apoptosis in cancer cells and inhibiting the growth of xenograft tumors in nude mice. Furthermore, LY2181308 has been shown to sensitize tumors to chemotherapeutic agents such as gemcitabine, paclitaxel and docetaxel. Due to its differential expression in normal tissues and its function in apoptosis, survivin is a promising target for cancer therapy (Carrasco et al., 2011).

Another promising study is miRNAs, which act as oncogenes and tumor suppressors in the development and metastasis of breast cancer. It is possible that the various roles that miRNAs play have the potential to provide valuable information in a clinical setting, demonstrating the potential to act as both screening tools for stratifying high-risk patients, while informing the decision-making process of treatment (Asia et al., 2018). The miR-143 marker was investigated through data from studies with patients with locally advanced triple negative breast cancer, discriminating the complete pathological response and the polymerase-free chain reaction, receiving neoadjuvant treatment based on fluorouracil-cisplatin / paclitaxel. MiR-143 has been 
shown to be a potential predictor of response to neoadjuvant therapy in triple negative breast cancer (García-Vázquez et al., 2019).

In another analysis, it highlights the tumor's circulating DNA (ctDNA), which is found in the bloodstream and refers to the DNA that comes from cancer cells and tumors. CtDNA are small pieces of DNA, usually comprising less than 200 nucleotide blocks in length. The study carried out by means of high-level sequencing of a personalized panel in blood samples, three somatically mutated genes were detected, PIK3CA, TP53 and KMT2C. This study was the first to explore the link between prognosis and ctDNA after neoadjuvant therapy in Chinese breast cancer patients. The incidence of KMT2C mutations was high in patients with breast cancer, especially among patients with triple-negative breast cancer (TNBC). Kaplan-Meier survival and multivariate analyzes show that KMT2C ctDNA could be a predictor of breast cancer recurrence, while the association between KMT2C and efficiency of neoadjuvant therapy was negligible. The study highlights the ability of ctDNA analysis at different times to assess tumor progression and treatment effectiveness, such as predicting breast cancer recurrence (Hao et al., 2020).

The increasing use of the monoclonal antibody trastuzumaboth against the extracellular site of the human epidermal growth factor receptor type 2 (HER2). Its use caused a decrease in the progression of breast cancer in patients who underwent chemotherapy treatment alone or in combination with trastuzumab. Therapy involving anti-HER-2 is an ideal modality, and blocking HER-2 by means of trastuzumab is effective in cases of initial or metastatic breast cancer (Haddad, 2010).

As verified in a study of TRPM2 expression (potential cationic channel of transient receptor), it was observed that the low expression of TRPM2 is used to predict bad results and a greater possibility of recurrence in relation to ER- and HER2 + breast carcinoma. Therefore, TRPM2 is a biomarker for new therapies (Sumoza-Toledo et al., 2016).

Attested by means of a study, in which 678 cases of breast cancer tissue were selected by means of immunohistochemical staining of hormone receptors and growth of human hypodermic, that the increase of the nuclear expression of YAP (regulatory protein of the transcription of genes of cell proliferation and suppression of apoptotic genes) is related to decreased overall survival rate in breast cancer and overexpression of cytoplasmic YAP in HER-2 type breast cancer in which it was associated with shorter disease-free survival rate. That through this, there is an important difference in the expression of YAP and pYAP according to the molecular subtypes and tumor components. Nuclear and cytoplasmic expression of YAP appears to be a prognostic marker for patients with breast cancer (Kim et al., 2014).

It was also shown that hormone receptor (HR) negativity and the high Ki67 protein index are two independent factors to predict a higher complete pathological response (pCR) in breast cancer positive for axillary / HER2-positive lymph nodes. In particular in patients with HR-negative / high Ki67 index, the pCR rate reached $70.0 \%$, suggesting that this patient population may obtain more benefits from neoadjuvant therapy containing paclitaxel, carboplatin and trastuzumab (Ding et al., 2017). We attest to the similarity of pCR biomarkers with the Ki67 marker, associated with cell proliferation and labeling index (LI) at baseline may be predictive of survival rates in patients with breast cancer with HER2 overexpression similar to luminal (Kurozumi, et al., 2015).

It was examined that the absence or low expression of the ADAM33 protein contributes to the increased aggressiveness and metastases of breast cancer. The present study has shown, in an unprecedented way, that ADAM33, in combination with currently available biomarkers, can be a new molecular marker to better determine the prognosis of breast cancer. The importance of ADAM33 in TNBC-negative triple carcinoma and basal-type carcinoma (BLBC) is clear and may improve our knowledge of the most aggressive breast cancer subtypes. In addition, LumA and LumB breast carcinomas showed a strong signal for ADAM33. Conferring that the absence of eobitus metastases was related to the high expression of ADAM33. These results suggest that ADAM33 may be a significant marker of good disease prognosis because breast carcinomas LumA and LumB are less aggressive compared to tumor subclasses HER2 +, TNBC and BLBC (Manica et al., 2017). 
The chemokine receptor (CXCR4) is a receptor coupled to transmembrane G protein seven and stimulating tumor growth, angiogenesis and metastasis in various types of cancer. It is a class of biomarker with predictive potential associated with promoting resistance to tamoxifen via the AKT (Protein kinase B) pathway. In addition, the AMD3100 CXCR4 antagonist reversed tamoxifen resistance in breast cancer by inhibiting AKT phosphorylation. As mentioned, the combination of endocrine therapy and other component inhibitors that mediate endocrine resistance is one of the suggested methods for breast cancer resistant to endocrine therapy. The combination of tamoxifen and AMD3100, a specific CXCR4 antagonist, can increase the tumor suppressor effects and reduce the potential side effects arising from the dosage of the drug (Zhou et al., 2020).

\section{Conclusion}

The results of this study demonstrate the biomarkers with substantial potential in the treatment of breast and prostate cancer. The management in which the results were presented, consider the use and assistance of biomarkers for chemotherapy / radiotherapy, in which they provide the prediction of responses to clinical treatment, and they are associated with better results. The clinical application of these predictive biomarkers can enable numerous advantages, among them, better adherence to treatment because it becomes a therapy based on the genetic individuality of a given patient. Consequently, with a more specific therapy, less toxicity and possible side effects are observed, which reduces expenses with medications and additional hospitalizations.

However, there are no universally accepted predictive markers of response to cancer treatment, and the few that have been investigated in the neoadjuvant context are most often predetermined markers are present. The accession of new biomarkers can expand the therapeutic regimen options currently available to doctors. Therefore, it is necessary to expand experiences to characterize the real value of using each biomarker in cancer therapy, since, currently, studies demonstrate positive results with safe, efficient and cost effective therapies with the help of pharmacogenetics.

\section{References}

Almeida, J. R. C., Pedrosa, N. L., Leite, J. B., Fleming, T. R. P., Carvalho, V. H. \& Cardoso, A. A. A. (2007). Tumor Markers: Literature Review. Revista Brasileira De Cancerologia, 53(3), 305-316.

Álvarez, M. P., Marcos, V. E., García, B. B. \& Isidoro, G. M. (2019). Farmacogenómica: La Medicina Personalizada. Revista Del LaboratorioClínico, 12, $147-154$.

Antonarakis, E. S., Lu, C.,Wang, H., Luber, B., Nakazawa, M., Roeser, J. C., Chen, Y., Mohammad, T. A., Chen, Y., Fedor, H. L., Lotan, T. L., Heng, Q., Marzo, A. M., Isaacs J. T., Isaacs, W. B., Nadal, R., Paller, C. J., Denmeade, S.R., Carducci, M. A., Eisenberger, M. A. \& Luo, J. (2014). Ar-V7 And Resistance to Enzalutamide and Abiraterone In Prostate Cancer. The New England Journal of Medicine, 371(11), $1028-1038$.

Antonarakis, E. S., Lu, C., Luber, B., Wang, H., Chen, Y., Zhu, Y., Silberstein, J. L., Taylor, M. N., Maughan, B. L., Denmeade, S. R., Pienta, K. J., Paller, C. J., Carducci, M. A., Eisenberger, M. A. \& Luo J. (2017). Clinical Significance of Androgen Receptor Splice Variant-7 Mrna Detection in Circulating Tumor Cells Of Men Withmetastatic Castration-Resistant Prostate Cancer Treated With First- And Second-Line Abiraterone And Enzalutamide. Journal of Clinical Oncology, 35 (19), 2149-2156.

Armstrong, C. M., Liu, C., Lou, W.; Lombard, A. P., Evans, C. P. and Gao, A. C. (2017). Microrna-181a PromotesDocetaxelResistance In ProstateCancerCells. The Prostate, 77 (9), 1020-1028.

Asiaf, A., Ahmad, S. T., Arjumand, W. \& Zargar, M. A. (2018). Micrornas In Breast Cancer: Diagnostic and Therapeutic Potential. Microrna And Cancer, $1699,23-43$.

Badani, K. K., Thompson, D. J. S., Brown, G., Holmes, D., Kella, N., Albala, D., Singh, A., Buerki, C., Vicioni, E D. \& Hornberger, J. (2015). Effect of A Genomic Classifier Test on Clinical Practice Decisions for Patients with High-Risk Prostate Cancer After Surgery. Bju International, 115 (3), $419-429$.

Badani, K. K., Thompson, D. J. S., Buerki, C., Davicioni, E., Garrison, J., Ghadessi, M., Mitra, A.P., Wood, P.J. \& Hornberger, J. (2013). Impact of A Genomic Classifier of Metastatic Risk on Postoperative Treatment Recommendations for Prostate Cancer Patients: A Report from The Decide Study Group. Oncotarget, 4 (4), 600-609.

Bownes, R. J., Turnbull, A. K., Martinez-Perez, C., Cameron, D. A., Sims, A. H. \& Oikonomidou, O. (2019). On-Treatment Biomarkers Can Improve Prediction of Response to Neoadjuvant Chemotherapy In Breast Cancer. Breast Cancer Research, 21 (1), 73. 
Carrasco, R. A., Stamm, N. B., Marcusson, E., Sandusky, G., Iversen, P. \& Patel, B. K. (2011). Antisense Inhibition of Survivin Expression As A Cancer Therapeutic. Molecular Cancer Therapeutics, 10 (2), 221-232.

Crawford, E. D., Scholz, M. C., Kar, A. J., Fegan, J. E., Haregewoin, A., Kaldate, R. R. \& Brawer, M. K. (2014). Cell Cycle Progression Score and Treatment Decisions in Prostate Cancer: Results from An Ongoing Registry. Current Medical Research and Opinion, 30 (6), $1025-1031$.

Ding, J., Yang, Y., Jiang, L., Wu, W. \& Shao, Z. (2017). Predictive Factors of Pathologic Complete Response in Her2-Positive And Axillary Lymph Node Positive Breast Cancer After Neoadjuvant Paclitaxel, Carboplatin Plus With Trastuzumab. Oncotarget, 8 (34), 56626-56634.

Estatísticas De Câncer. (2020). Instituto Nacional de Câncer. https://www.inca.gov.br/numeros-de-cancer. Acessed: January 2021.

Fan, L., Yang, Y., Chi, C., Ma, X., Wang, R., Gong, Y., Zheng, H., Pan, J., Zhu Y., Dong B. \& Xue, W. (2019). Neuroendocrine Differentiation Markers Guide Treatment Sequence Selection in Metastatic Castration-Resistant Prostate Cancer. The Prostate, 79 (6), $567-573$.

Fricke, G., Jung, G. H.; Lerena, A. \& López, L. M. (2018). Pharmacogenetics of Adverse Reactions to Antiepileptic Drugs. Neurología (EnglishEdition), 33 (3), 165-176.

García-Vázquez, R., Marchat, L. A., Ruíz-García, E., De La Vega, H.A., Meneses-García, A., Arce-Salinas, C., Bargallo-Rocha, E., Carlos-Reyes, Á., LópezGonzález, J.S., Pérez-Plasencia, C., Ramos-Payán, R., Aguilar-Medina, M. \& López-Camarillo, C. (2019). Microrna-143 Is Associated with Pathological Complete Response and Regulates Multiple Signaling Proteins in Breast Cancer. Technology in Cancer Research \& Treatment, $18,1-11$.

Genitsch, V., Zlobec, I., Seiler, R., Thalmann, G.N. \& Fleischmann, A. (2017). Neuroendocrine Differentiation In Metastatic Conventional Prostate Cancer Is Significantly Increased In Lymph Node Metastases Compared To The Primary Tumors. International Journal of Molecular Sciences, 18 (8), 1640.

Haddad, C.F. (2010). Trastuzumab In Breast Cancer. Feminina, 38 (2), 73-78.

Hao, S., Tian, W., Zhao, J., Chen, Y., Zhang, X., Gao, B., He, Y. \& Luo, D. (2020). Analysis of Circulating Tumor Dna To Predict Neoadjuvant Therapy Effectiveness and Breast Cancer Recurrence. Journal of Breast Cancer, 23 (4), 373-384.

Jung, K., Miller, K., Wirth, M., Albrecht, M. \& Lein, M. (2011). Bone Turnover Markers as Predictors Of Mortality Risk In Prostate Cancer Patients With Bone Metastases Following Treatment With Zoledronic Acid. European Urology, 59 (2011), 604-612.

Kim, S. K., Jung, W. H. \& Koo, J. S. (2014). Yes-Associated Protein (Yap) Is Differentially Expressed In Tumor And Stroma According To The Molecular Subtype Of Breast Cancer. International Journal of Clinical and Experimental Pathology, 7 (6), 3224-3234

Klopp-Schulze, L., Mueller-Schoell, A., Neven, P., Koolen, S., Mathijssen, R., Joerger, M. \& Kloft, C. (2020). Integrated Data Analysis Of Six Clinical Studies Points Toward Model-Informed Precision Dosing Of Tamoxifen. Frontiers in Pharmacology, 11, 283.

Kurozumi, S., Inoue, K., Takei, H., Matsumoto, H., Kurosumi, M., Horiguchi, J. \& Oyama, T. (2015). Er, Pgr, Ki67, P27 Kip1, And Histological Grade As Predictors Of Pathological Complete Response In Patients With Her2-Positive Breast Cancer Receiving Neoadjuvant Chemotherapy Using Taxanes Followed By Fluorouracil, Epirubicin, And Cyclophosphamide Concomitant With Trastuzumab. Bmc Cancer, 15, 622.

Lara, M. P., Jr.; Ely, B., Quinn, Q. I., Mack, P.C., Tangen, C., Gertz, E., Twardowski, P. W., Goldkorn, A., Hussain, M., Vogelzang, N. J., Thompson, I. M. \& Loan. M. D. V. (2014). Serum Biomarkers of Bone Metabolism in Castration-Resistant Prostate Cancer Patients with Skeletal Metastases: Results from Swog 0421. Journal of The National Cancer Institute, 106 (4), 1-9.

Manica, G. C., Ribeiro, C. F., Oliveira, M. A., Pereira, I. T., Chequin, A., Ramos, E. A., Klassen, L. M., Sebastião, A. P., Alvarenga, L. M., Zanata, S. M., Noronha, L., Rabinovich, I., Costa, F. F., Souza, E. M. \& Klassen, G. (2017). Down Regulation of Adam33 As A Predictive Biomarker of Aggressive Breast Cancer. Scientific Reports, 7, 44414 .

Markowshi, M.C., Silberstein, J.L., Eshleman, J.R., Eisenberger, M.A., Luo, J. \& Antonarakis, E.S. (2017). Clinical Utility of Clia-Grade Ar-V7 Testing In Patients With Metastatic Castration-Resistant Prostate Cancer. Na American Society of Clinical Oncology Journal, 1, 1-9.

Michalopoulos, S. N., Kella, N., Payne, R., Yohannes, P., Singh, A., Hettinger, C., Yousefi, K. \& Hornberger, J. (2014). Influence of A Genomic Classifier On Post-Operative Treatment Decisions In High-Risk Prostate Cancer Patients: Results From The Pro-Act Study. Current Medical Research and Opinion, 30 (8), $1547-1556$

Miyamoto, T. D., Lee, R. J.; Kalinich, M., Licausi, J. A., Zheng, Y., Chen, T., Milner, J. D., Emmons, E., Ho, U., Broderick, K., Silva, E., Javaid, S., Kwan, T. T., Hong, X., Dahl, Dm., Mcgovern, F. J., Efstathiou, J. A., Sequist, L. V., Kapur, R., Wu, C., Stott, S. L., Ting, D. T., Giobbie-Hurder, A., Toner, M., Maheswaran, S. \& Haber, D.A. (2018). An Rna-Based Digital Circulating Tumor Cell Signature Is PredictiveOf Drug Response and Early Dissemination In Prostate Cancer. Cancer Discovery, 8 (3), 288-303.

Moul, J. W., Chen, D. Y. T., Trabulsi, E. J., Warlick, C. A., Ruckle, H. C., Porter, J. R., Yoshida, J. S., Adams, G. W., Kella, N., Matsunaga, G. S., Bans, L. L., Sarno, M. J., Mcdermed, J. E., Triebell, M.T. \& Reynolds, M. A. (2014). Impact of Nadia ProsvuePsa Slope on Secondary Treatment Decisions After Radical Prostatectomy. Prostate Cancer And Prostatic Diseases, 17 (3), 280-285.

Santos, B. G. Q. (2017). A Aplicação Da Farmacogenética Em Contexto De Farmácia Hospitalar. Tese Instituto Universitário Egas Moniz.

Santos, S. L. F., Pessoa, C. V., Alves, H. H. S., Oliveira, C. P. A. \& Barros, K. B. N. T. (2016). Pharmacogenética Aplicada À Oncologia: Realidade Brasileira E Perspectivas Na Prática Clínica. Boletim Informativo Geum, 7 (3), 49-55.

Sandler, H., Klein, E. A., Black, P., Seiler, R., Tomlins, A., Chinnaiyan, A. M., Jenkins, R. B., Davicioni, E., Ross, A. E., Schaeffer, E. M., Nguyen, P. L., Carroll, P. R., Karnes, R. J., Spratt, D. E. \& Feng, F. Y. (2017). Associations of Luminal and Basal Subtyping of Prostate Cancer with Prognosis And Response To Androgen Deprivation Therapy. Jama Oncology, 3 (12), 1663-1672.

Saxby, H., Mikropoulos, C. \& Boussios, S. (2020). An Update on The Prognostic and Predictive Serum Biomarkers In Metastatic Prostate Cancer. Diagnostics, 10 (8), 549. 
Shi, G., Ye, D., Yao, S., Zhang, S., Dai, B., Zhang, H., Shen, Y., Zhu, Y., Zhu, Y., Xiao, W. \& Ma, C. (2010). Involvement of Microrna-21 In Mediating Chemo-Resistance to Docetaxel in Androgen-Independent Prostate Cancer Pc3 Cells. Acta Pharmacologica Sinica, 31(7), 867-873.

Schilling, M., Silva, I., Opitz, S., Borges, M., Koifman, S. \& Koifman, R. (2017). Breast Cancer Awareness among Women in Western Amazon: a Population Based Cross-Sectional Study. Revista Da Ásia-Pacífico Sobre Prevenção Do Câncer: Apjcp, 18(3), 847-856.

Shokouh, T. Z., Ezatollah, A. \& Barand, P. (2015). Interrelationships Between Ki67, Her2/Neu, P53, Er, And Pr Status and Their Associations with Tumor Grade and Lymph Node Involvement In Breast Carcinoma Subtypes: Retrospective-Observational Analytical Study. Medicine, 94 (32), 1359.

Shore, N. D., Kella, N., Moran, B., Boczko, J., Bianco, F. J., Crawford, E. D., Davis, T., Roundy, K. M., Rushton, K., Grier, C., Kaldate, R., Brawer, M. K. \& Gonzalgo, M. L. (2016, march). Impact of The Cell Cycle Progression Test on Physician And Patient Treatment Selection For Localized Prostate Cancer. The Journal of Urology, 195 (3), 612-618.

Someya, M., Hori, M., Gocho, T., Nakata, K., Tsuchiya, T., Kitagawa, M., Hasegawa, T., Fukushima, Y. \& Sakata, K. (2018). Prediction of Acute Gastrointestinal And Genitourinary Radiation Toxicity In Prostate Cancer Patients Using Lymphocyte Microrna. O Japanese Journal of Clinical Oncology, 48 (2), 167-174.

Sumoza-Toledo, A., Espinoza-Gabriel, M.I. \& Montiel-Condado, D. (2016). Evaluation of The Trpm2 Channel As A Biomarker In Breast Cancer Using Public Databases Analysis. Boletín Médico Del Hospital Infantil De México (English Edition), 73(6), $397-404$.

Tan, Q. X., Qin, Q.H., Yang, W.P., Mo, Q.G. \& Wei, C.Y. (2014). Prognostic Value of Ki67 Expression In Hr-Negative Breast Cancer Before And After Neoadjuvant Chemotherapy. International Journal of Clinical and Experimental Pathology, 7 (10), 6862-6870.

Zhao, S. G., Chang, S. L., Erho, N., Yu, M., Lehrer, J., Alshalalfa, M., Speers, C., Cooperberg, M. R., Kim, W., Ryan, C. J., Den, R. B., Freedland, S. J., Posadas, E.,

Zhou, J., Le, K., Xu, M., Ming, J., Yang, W., Zhang, Q., Lu, L., Xi, Z., Ruan, S. \& Huang, T. (2020). Cxcr4 Antagonist Amd3100 Reverses the Resistance To Tamoxifen In Breast Cancer Via Inhibiting Akt Phosphorylation. Molecular Therapy Oncolytics, 18, 161-170.

Zhou, J., Li, W., Ming, J., Yang, W., Lu, L., Zhang, Q., Ruan, S. \& Huang, T. (2020). High Expression of Traf4 Predicts Poor Prognosis In TamoxifenTreated Breast Cancer And Promotes Tamoxifen Resistance. Anti-Cancer Drugs, 31 (6), 558-566. 